\title{
Wyrok Sądu Międzydiecezjalnego w Grodnie c. Gałązka z 30 maja 1995 r. w sprawie o nieważność małżeństwa z tytułu braku formy kanonicznej
}

Ius Matrimoniale 1 (67), 243-253

1996

Artykuł został zdigitalizowany i opracowany do udostępnienia w internecie przez Muzeum Historii Polski w ramach prac podejmowanych na rzecz zapewnienia otwartego, powszechnego i trwałego dostępu do polskiego dorobku naukowego i kulturalnego. Artykuł jest umieszczony w kolekcji cyfrowej bazhum.muzhp.pl, gromadzącej zawartość polskich czasopism humanistycznych i społecznych.

Tekst jest udostępniony do wykorzystania w ramach dozwolonego użytku. 


\section{Wyrok Sądu Międzydiecezjalnego w Grodnie c. Galązka z 30 maja 1995 r. w sprawie o nieważność małżeństwa $\mathrm{z}$ tytułu braku formy kanonicznej}

\section{Przebieg sprawy}

Dnia 18 lutego 1961 r. w urzędzie: Zapis Aktow Grażdanskogo Sostojanija w Pałłasówce w Wołgogradskoj Obłasti w Rosji, zawarty został cywilny związek małżeński pomiędzy Aleksandrem L., kawalerem wyznania prawosławnego, i Emmą W., panną wyznania rzymskokatolickiego. Wspólnota małżeńska trwała ok. 5 lat. Dnia 26 IX 1992 r. do Sądu Kościelnego w Grodnie wpłynęła skarga powodowa Emmy o orzeczenie nieważności tego małżeństwa. Sąd przyjął skargę dnia 25 I 1993 r. Instrukcję dowodową rozpoczęto 29 V 1993 r., zakończono 25 X 1994 r. W jej toku, przesłuchano powódkę i 4 świadków. Przyjęto dowód z dokumentu. Strony nie skorzystały z prawa zapoznania się z aktami sprawy, odpowiedziały na przedwyrokowe uwagi Obrońcy węzła małżeńskiego. W dniu dzisiejszym Sędziowie przystapili do wyrokowania, stawiając sobie do rozstrzygnięcia watpliwość: czy udowodniona została nieważność małżeństwa W. - Ł. z tytułu braku nadzwyczajnej formy kanonicznej?

\section{Prawne podstawy orzeczenia}

Małżeństwo W. - Ł. zostało zawarte w okresie obowiązywalności Kodeksu Prawa Kanonicznego z 1917 roku, dlatego ocenę ważności tego małżeństwa należy oprzeć na przepisach tego Kodeksu, chociaż Kodeks Prawa Kanonicznego z 1983 r. nie wprowadził w tej kwestii istotnych zmian. Przepisami Kodeksu Prawa Kanonicznego z 1983 r. w niniejszej sprawie należy posługiwać się tylko w odniesieniu do procedury procesowej. Kodeks z 1917 roku stanowił, że osoba ochrzczona w kościele katolickim może zawrzeć małżeństwo $\mathrm{z}$ osobą tego samego lub innego 
wyznania (kanon $1099 \S 1,1^{\circ}$ i $2^{\circ}$ ) tylko wobec proboszcza lub ordynariusza miejsca albo kapłana delegowanego przez jednego $\mathrm{z}$ nich i dwóch przynajmniej świadków (kanon 1094). Gdyby jednak kapłan upoważniony do asystowania przy zawarciu małżeństwa był niemożliwy do osiagnięcia bez wielkiej trudności można było zawrzeć małżeństwo wobec samych świadków (bez kapłana) w niebezpieczeństwie śmierci, albo poza niebezpieczeństwem śmierci, jeśli roztropnie przewidywano, że taka sytuacja będzie trwała jeszcze przynajmniej przez miesiąc (kanon 1098, $1^{\circ}$ ). Ma tutaj miejsce nadzwyczajna forma kanoniczna zawarcia małżeństwa. Nie miałaby ona zastosowania, gdyby nowożeńcy, nie mogąc udać się do własnego proboszcza, mogliby udać się do proboszcza w innej blisko położonej miejscowości (Komisja Interpretacyjna Kodeksu Prawa Kanonicznego, dnia 10 III 1928; 25 VII 1931, 3 V 1945 r.). Kodeks nie podawał wobec ilu świadków należy zawierać małżeństwo w wypadku zastosowania formy nadzwyczajnej, użył jednak słów „coram solis testibus” (wobec samych świadków), co w zestawieniu z kanonem 1094 mówiącym o zwyczajnej formie kanonicznej słowami „coram duobus testis” (wobec dwóch świadków), kazał domyślać się, że również przy zastosowaniu formy nadzwyczajnej świadków tych ma być co najmniej dwóch. Tak rozumieli to kanoniści. Tak również rozumie ten przepis Instrukcja Kongregacji Sakramentów z dnia 7 XII 1971 r. stwierdzając: „kan. 1098, który postanawia, że ważne jest małżeństwo zawarte wobec samych dwóch świadków" (Zob. Posoborowe Prawodawstwo Kościelne, t. VI, z. 2, Warszawa 1975 r., s. 363). Prawo nie mówi w jakim miejscu ma być zawierane małżeństwo według formy nadzwyczajnej, można więc zawrzeć je w każdym miejscu, w tym również w urzędzie stanu cywilnego zgodnie z przepisami cywilnymi danego kraju (Por. T. Pawluk, Prawo kanoniczne t. III, Olsztyn 1984, s. 187). Oczywiste jest, że ważne małżeństwo można zawrzeć tylko wtedy, gdy pomiędzy nowożeńcami nie ma przeszkód kanonicznych. Nowożeńcy nie muszą znać prawa kanonicznego na tyle, aby wiedzieć o istnieniu nadzwyczajnej formy zawarcia małżeństwa. Wystarczy, że pragna zawrzeć prawdziwe małżeństwo. Tak zawarte małżeństwo jest małżeństwem ważnym, sakramentalnym, nie wymagającym później ponowienia wobec kapłana. Można jedynie poprosić go o błogosławieństwo. Według Kodeksu Prawa Kanonicznego z 1917 roku do zachowania katolickiej formy zawarcia małżeństwa zobowiązane były . 
wszystkie osoby ochrzczone w kościele katolickim albo przyjęte od niego, nawet, gdyby odstapili od wiary katolickiej (kan. $1099 \S 1,1^{\circ}$ i $2^{\circ}$ ).

Gdyby jednak okazało się, że tak zawarte małżeństwo było nieważne z powodu jakiejś przeszkody prawnej, strony mogłyby je uważnić zgodnie z przepisami prawa (kan. 1133-1141), albo zwrócić się do właściwego sądu kościelnego, aby orzekł jego nieważność. Tę nieważnośc należy udowodnić, bowiem prawo domniemywa, że każde małżeństwo jest ważne (kan. 1014. To samo kan. 1060 KPK z 1983 r.). W odniesieniu do terenów na których nie było kapłanów należy domniemywać, że ważne są małżeństwa zawarte zgodnie z miejscowym prawem lub zwyczajem, byleby odpowiadaly wymogom formy nadzwyczajnej. Obowiązek dowodzenia spoczywa na tym, kto twierdzi, że było ono zawarte nieważnie (kan. $1526 \S$ 1 KPK z 1983 r.).

W aktach sprawy o orzeczenie nieważności małżeństwa W. $-\ell$. nie ma świadectwa chrztu, ani żadnego urzędowego dokumentu $\mathrm{z}$ którego wynikałoby, że strony procesowe były zobowiązane do kanonicznej formy zawarcia małżeństwa, a mianowicie, że przynajmniej jedna $z$ nich była ochrzczona w kościele katolickim, albo formalnie przyjęta do niego. Jest faktem notorycznym, że w okresie urodzenia stron i w okresie zawierania przez nie małżeństwa, na terenie Związku Socjalistycznych Republik Radzieckich nie istniała organizacja kościelna, a jakakolwiek religia była prześladowana. Nie może więc być żadnych autentycznych dokumentów kościelnych z tego okresu. Co więcej: duchowni jakiegokolwiek wyznania w tym okresie (poza nielicznymi wyjątkami) nie tylko nie mogli wypełniać czynności religijnych, ale też byli pozbawieni wolności. Sakramentu chrztu udzielali ludzie świeccy. W takich przypadkach to, czy chrzest został udzielony w kościele katolickim, czy w jakimś wyznaniu niekatolickim zależy od samego przyjmującego chrzest, jeśli w chwili chrztu miał już używanie rozumu, jeśli natomiast był jeszcze dzieckiem, od osób, od których prawnie był zależny (rodziców lub opiekunów), albo od osoby udzielajacej chrztu (C. Off., 1 VIII 1883, Fontes, IV, n. 1083; Dec. 23 z r. 1910; Dec. 24 z r. 1911).

W procesie o orzeczenie nieważności małżeństwa W. - L. najpierw trzeba udowodnić że przynajmniej jedna $z$ osób zawierających to małżeństwo została ochrzczona w Kościele katolickim, a tym samym zobowiązana do katolickiej formy zawarcia małżeństwa. Następnie należy zbadać, czy przy jego zawieraniu niemożliwe było zastosowanie 
zwyczajnej formy kanonicznej, to znaczy zawrzeć go w obecności właściwego proboszcza i dwóch świadków. Stwierdzenie niemożliwości zastosowania formy zwyczajnej uzasadniało zastosowanie przez nowożeńców nadzwyczajnej formy kanonicznej. Czy jednak forma nadzwyczajna została zastosowana prawidłowo, a wiec, czy małżeństwo to zostało zawarte w obecności dwóch świadków zwyczajnych? Po stwierdzeniu braku nadzwyczajnej formy kanonicznej należy jeszcze upewnić się, czy nieważnie zawarte małżeństwo nie zostało w przyszłości konwalidowane.

\section{Faktyczne podstawy orzeczenia}

\section{Czy strony byly zobowiązane do katolickiej formy zawarcia malżeństwa?}

Powódka urodziła się na Syberii, gdzie jej rodzice zostali zesłani w ramach stalinowskich represji wobec Niemców Nadwołżańskich. Niemożliwy jest dowód jej katolickiego chrztu w postaci dokumentu. Nie mogła ona być ochrzczona $w$ kościele, bo w tym czasie światynie w Związku Radzieckim były pozamykane. W skardze powodowej napisała: „Za 3 miesiące (po jej urodzeniu) ojca zabrano do armi pracy, potem umarła matka i ja zostałam razem $\mathrm{z}$ babką. Ona była bardzo wierząca, katoliczka i moi rodzice też. Bardzo wcześnie babka nauczyła mnie modlić się i ona mnie ochrzciła" (k. 1). W zaprzysiężonych zeznaniach powódka oświadczyła: „Oboje moi rodzice byli katolikami. Ja byłam ochrzczona we wsi Jełanka w domu, dlatego, że u nas nie było kościoła. To było niezwłocznie po moim urodzeniu w 1942 roku. Chrzciła mnie moja babka, która była szczerą katoliczka... Nigdy nie zapisywałam się do jakiegokolwiek innego wyznania religijnego... zawsze byłam katoliczka. O tym, że zostałam ochrzczona przez osobę wyznania katolickiego wiem od mojej babki i od ojca... O tym, że byłam ochrzczona przez osobę wyznania katolickiego słyszeli... wszyscy parafianie katolickiej parafii w Pałłasówce, z którymi przed wojną moi rodzice mieszkali w jednej wsi" (k. 23). Powódka w skardze powodowej pisze o swojej chrzestnej matce, do której po swoim nawróceniu w 1982 roku zwróciła się o pomoc w umocnieniu odzyskanej wiary (k. 2v). 
Fakt chrztu powódki przez jej babkę, należąca, podobnie jak rodzice powódki do Kościoła katolickiego potwierdzili: pozwany: ,rodzice Emmy byli katolikami... Ona zawsze trzymała się wiary swoich przodków... od niej samej dowiedziałem się, że była chrzczona po katolicku" (k. 28) i świadkowie: Jakow R.: ",Rodzice Emmy byli rzymskokatolikami... O chrzcie Emmy przez osobę wyznania katolickiego dowiedziałem się od ojca Emmy” (k. 47) i Franciszka H.: „Babka która ją chrzciła była katoliczką... dowiedziałem się o tym od jej babki" (k. 49).

Powódka nie jest pewna przynależności wyznaniowej pozwanego. Słyszała, że był on ochrzczony w dzieciństwie $(k .1,24)$, ale nie wie w jakim wyznaniu religijnym. W skardze powodowej podaje, że jego matka „chodziła do sekty baptystów” (k. 1v), w zaprzysiężonych zeznaniach stwierdza: „L. mówił mi, że chrzciła go obca babka. Nie wiem jakiego wyznania była ta babka" (k. 24). Pozwany sam jednak wyraźnie oświadczył pod przysiega: ,Jestem wyznania prawosławnego" (k. 28). Moi rodzice byli wyznania prawosławnego. Ochrzcił mnie starszy wiekiem we wsi w której urodziłem się. Był on wyznania prawosławnego. Ja nigdy nie przyjmowałem wyznania katolickiego" (k. 29).

Swiadkowie nie wiedzą jakiego wyznania jest pozwany, niektórzy tylko domyślają się jego pochodzenia od rodziców prawosławnych. „Ojca Ł. nie znałem, a matka według mego przekonania należała do wyznania prawosławnego" (J. R. - k. 47v). „Rodzice pozwanego byli prawosławnymi. Aleksander $Ł$. należał do wyznania rosyjskoprawosławnego" (W. S. - k. 50v).

\section{Czy bylo możliwe zastosowanie zwyczajnej formy zawarcia malżeństwa?}

W skardze powodowej powódka napisała: „W tym czasie nie było u nas kościola i o ślubie kościelnym nie było mowy" (k. 1v). W zeznaniach powódka oświadczyła: „W 1961 roku nikt w Połłasówce nie wiedział gdzie znajduje się najbliższy kapłan katolicki... W 1961 roku nie było możliwe udać się do kapłana katolickiego, aby tam wziąć ślub kościelny... było to zabronione polityką władz. Nie było wtedy żadnej nadziei, że w Pałłasówce, albo gdziekolwiek w pobliżu w przeciągu miesiąca będzie katolicki kapłan" (k. 24). 
Podobnie zeznał pozwany: „W 1961 roku nikt nie wiedział gdzie znajduje się najbliższy kapłan prawosławny, a tym bardziej katolicki. W tym czasie na tym terytorium w ogóle nie było nigdzie kapłanów katolickich. Nie było możliwości udać się do kapłana katolickiego nawet dla uzasadnionej przyczyny... religia była narażona na prześladowanie. Nigdy nie było żadnej nadziei, że w Pałłasówce, albo gdziekolwiek w pobliżu będzie mieszkał katolicki kapłan" (k. 29).

Świadkowie nie wiedzą o istnieniu w 1961 r. w Pałłasówce, albo w okolicy jakiegokolwiek kapłana katolickiego (J. R. - k. 47v, N. F. - k. $51 v$ ). Niektórzy z nich wprost twierdza, że takiego kapłana nie było (F. H. k. 49v, W. S. - k. 50v). Świadkowie zgodnie nie wiedzą o możliwości udania się w tym okresie gdziekolwiek do kapłana katolickiego w celu zawarcia wobec niego małżeństwa (F. H. - k. 49v, W. S. - k. 50v, N. F. k. $51 \mathrm{v}$ ). Jeden tylko świadek J. R. zeznał, że gdyby strony chciały, to mogły bez poważnych trudności udać się do Ałma Ata, gdzie był wtedy kapłan katolicki. Dodaje jednak, że jest to odległość około czterech tysięcy kilometrów (k. 47v). Świadek ten jednak w tym okresie mieszkał w Ałma Ata i nie znał sytuacji w Pałłasówce, gdzie, według świadka F. H. ludzie „żyli źle pod względem materialnym i nie mieli środków na wyjazdy gdziekolwiek" (k. 49).

Świadkowie nie wiedza, czy była nadzieja, że w przeciagu miesiąca może pojawić się w Pałłasówce albo w okolicy kapłan katolicki, który mógłby asystować przy zawieraniu małżeństw (k. 47v, 50v, 51v). F. H. wprost oświadczyła: „Myśmy w ogóle nie myśleli, że w Pałłasówce, albo gdziekolwiek w okolicy Pałłasówki będzie w przeciągu miesiąca katolicki kaptan" (k. 49v).

Niepodważalnym dowodem, czy było możliwe zastosowanie zwyczajnej formy kanonicznej jest urzędowe stwierdzenie Ka. Arcybiskupa Tadeusza Kondrusiewicza, Administratora Apostolskiego dla Katolików Obrządku Lacińskiego Europejskiej części Rosji: „według mojego rozeznania w roku 1961 w Pałłasówce (Wołg. obł) nie było księdza katolickiego, gdyż w owym czasie w całej Rosji były czynne tylko dwa kościoły w Moskwie i Leningradzie. Natomiast nie da się wykluczyć, że jakiś kapłan mógł od czasu do czasu przybywać do Pałłasówki, gdzie są Niemcy, mając na uwadze niedaleki stosunkowo Kazachstan" (k. 33). 


\section{Czy nadzwyczajna forma kanoniczna zawarcia tego małżeństwa zostala zastosowana prawidlowo?}

Już w skardze powodowej powódka napisała, że podczas ślubu cywilnego ,w gabinecie ZAGS-u była tylko jedna kobieta, która zarejestrowała nasz ślub" (k. 1v). W zaprzysiężonych zeznaniach oświadczyła: „Na zawarcie małżeństwa udaliśmy się sami tylko we dwoje. Nie było z nami bliskich, przyjaciót, znajomych. W momencie zawierania małżeństwa $w$ ZAGS-ie oprócz urzędnika rejestrującego nasz ślub, a także mnie i Aleksandra nie było nikogo" (k. 24).

Dokładniej tę okoliczność wyjaśnił pozwany: „Do ZAGS-u na zawarcie małżeństwa przybyłem tylko ja z Emmą. Nie było ani krewnych, ani przyjaciół, ani znajomych. W ZAGS-ie oprócz osoby rejestrującej mój ślub z Emmą nie było więcej nikogo. W tym czasie był taki porządek rzeczy, że rejestracja odbywała się bez obecności świadków" (k. 29).

Spośród świadków tylko F. H. potwierdziła tę okoliczność: „Oprócz Emmy, Aleksandra i urzęanika rejestrujacego ślub nie było w ZAGS-ie nikogo. Dowiedziałam się o tym od Emmy i Aleksandra po weselu. W 60-tych latach rejestrowano śluby bez świadków" (k. 49v). Inni świadkowie zeznajacy w procesie nie znają okoliczności zawarcia tego małżeństwa.

\section{Czy nieważne matżenstwo stron bylo konwalidowane w przyszlości?}

Obydwie strony wyraźnie zeznały, że nigdy nie zawierały pomiędzy sobą ślubu kościelnego, ani nie podejmowały prób uważnienia swojego małżeństwa wobec Kościoła katolickiego (k. 24v, 29v). Również wszyscy świadkowie zgodnie oświadczyli, że o czymś takim nigdy nie słyszeli (k. $47-48,49,50,51)$.

\section{Ocena materiału dowodowego}

Nie ulega wątpliwości, że powódka została ochrzczona w Kościele katolickim, a tym samym zobowiazana do kanonicznej formy zawarcia małżeństwa. Z moralną pewnością można uznać, że pozwany został ochrzczony w wyznaniu prawosławnym. Pomiędzy nowożeńcami istniała 
więc przeszkoda różności wyznania zabraniająca im zawarcia małżeństwa (kan. 1060). Uzyskanie dyspensy od tej przeszkody nie było możliwe ze względu na brak organizacji kościelnej na terenach Związku Radzieckiego. Nie była to jednak przeszkoda rozrywająca. Zawarcie małżeństwa $z$ ta przeszkodą bez dyspensy, jakkolwiek zabronione dla katolików, nie powodowało jego nieważności (kan. 1036 § 1). Rozrywających przeszkód kanonicznych pomiędzy nowożeńcami nie było.

W miejscu zamieszkania stron $w$ czasie zawierania przez nie małżeństwa nie było organizacji kościelnej. Brak dostępu do kapłanów stwierdziły $w$ swoich zeznaniach nie tylko strony procesowe, ale te $z$ potwierdzili świadkowie. Ewentualne watpliwości co do tego rozstrzyga urzędowe stwierdzenie Abpa T. Kondrusiewicza z Moskwy. Najbliższy urzędujący kapłan katolicki był w Moskwie, blisko półtora tysiąca kilometrów od miejsca zamieszkania stron (nie w Ałma Ata, jak uważa jeden ze świadków). Pomimo iż jeden ze świadków jest zdania, że strony mogły bez wielkiej niedogodności udać się do Ałma Aty (4000 km) w celu zawarcia małżeństwa wobec kapłana katolickiego (k. 47), należy przyjąc, że byłoby to związane $z$ wielką niedogodnością, jakiej prawo nie wymaga. Taki wyjazd był kosztowny, a jak zeznal jeden ze świadków w tym czasie ludzie żyli biednie i nie mieli wielkich środków finansowych (k. 49). Ponadto wyjazd taki musiałby trwać kilka lub kilkanaście dni, a strony nie mogły łatwo opuścić swego miejsca pracy. Zgodnie z zasada, że w tym co dotyczy prawa czysto kościelnego ( $w$ tym wypadku forma kanoniczna małżeństwa), nie można wymagać od człowieka nadzwyczajnych wysiłków, należy uznać za udowodnione, że urzędujący świadek zawarcia małżeństwa (proboszcz lub ordynariusz) był dla stron nieosiagalny. Nie było też nadziei, że będzie on osiagalny w przeciagu miesiąca, jak wymaga tego przepis prawa kanonicznego. Nie przeczy temu zdanie stwierdzenie ks. abpa T. Kondrusiewicza, że z pobliskiego Kazachstanu mógł sporadycznie pojawić się jakiś kapłan (k. 33). Rzeczywiście po uwolnieniu kapłanów z łagrów $w$ połowie lat pięćdziesiątych, wielu $z$ nich potajemnie wędrowało zwłaszcza po Kazachstanie, aby napotykanym wiernym udzielać posług religijnych. Gdyby jednak taki kapłan pojawil się w Pałłasówce, to byłby to fakt nieprzewidywalny, bowiem tacy kapłani ukrywając się, nie powiadamiali o terminie swego przybycia do jakiejś miejscowości. Gdyby taki kapłan był obecny przy zawieraniu małżeństwa, byłby to tylko świadek zwyczajny według nadzwyczajnej formy kanonicznej (kan. $10982^{\circ}$ ), bo nie 
bylby to proboszcz wlasny (kan. $1095, \S 1,2^{\circ}$ ). Jego obecność nie miałaby wpływu na ważność zawieranego małżeństwa.

Obydwie strony procesowe $\mathrm{w}$ odpowiedziach na przedwyrokowe uwagi Obrońcy węzła małżeńskiego oświadczyły, że przy zawieraniu pomiędzy sobą małżeństwa w 1961 roku nie miały intencji zastosowania kanonicznej formy zawarcia małżeństwa (k. 60,62). Jednak przy nadzwyczajnej formie kanonicznej nowożeńcy nie muszą mieć woli zastosowania jej. Trudno przecież wymagać od przeciętnego wiernego szczególowej znajomości prawa kanonicznego. Wystarczy, że mają intencję zawarcia pomiędzy sobą prawdziwego małżeństwa (Autorów tak uważających podaje $F$. Bączkiewicz, Prawo kanoniczne, Opole 1958, t. II, s. 296, przypis 11). Nie ma podstaw do watpienia, że strony zawierając małżeństwo w ZAGS-ie miały intencję zawarcia prawdziwego malżeństwa. Zrozumiałe jest, że nie pragnęły wtedy zawrzeć małżeństwa według formy katolickiej, bo było to wtedy niemożliwe, a ponadto w tym czasie obydwie strony były niereligijne i nie przywiązywały wagi do obrzędów religijnych. Prawnie jednak powódka nie przestała być zobowiąana do katolickiej formy zawarcia małżeństwa.

Niezachowanie kanonicznej formy zawarcia małżeństwa W. - Ł., jakkolwiek będące głównym przedmiotem procesu, zostało udowodnione najsłabiej ze wszystkich wątpliwości, jakie ten proces ma wyświetlić. Wprawdzie strony zgodnie zeznały pod przysięga, że podczas zawierania ich małżeństwa była obecna tylko jedna osoba, rejestrująca to małżeństwo, ale ich zeznania potwierdził pod przysięga tylko jeden świadek. Zrozumiałe jest, że z natury rzeczy najtrudniej jest udowodnić brak świadków, bo jak udowodnić coś przy czym się nie było. W takim procesie możliwy jest tylko świadek ze słyszenia od stron, który uzyskał wiadomości w czasie niepodejrzanym. Dlaczego strony mają tak mało świadków na tę okoliczność? Od ich ślubu upłynęło już ponad trzydzieści lat. Trudno więc o świadków po tak długim okresie czasu. Można też uznać, że nie był to temat szczególnych rozmów. Zawieranie małżeństw w ZAGS-ie bez świadków było w tym czasie zwyczajną praktyką w Pałłasówce (k. 29, 49), pomimo iż miasto to liczy więcej jak 10000 , a mniej jak 100000 mieszkańców. Nie powinno być trudności ze znalezieniem świadków ślubu. Zawarcie tego małżeństwa nie odbiegało więc od zawierania innych małżeństw, a opowiada się coś zwykle coś co było nietypowe, charakterystyczne. Należy jednak uznać za udowodnione niezastosowanie 
kanonicznej formy nadzwyczajnej. Wśród środków dowodowych prawo kanoniczne wymienia przecież dowód $\mathrm{z}$ oświadczenia stron, a obydwie strony procesowe zgodnie zeznały, że podczas zawierania ich małżeństwa nie było dwóch świadków zwyczajnych. Zeznania te należy uznać za niepodejrzane. Już w pierwszym piśmie do Sądu Kościelnego powódka opisując historię swego życia podaje ten szczegół. Nie zna ona prawa kanonicznego i nie wiedziała, że to może mieć znaczenie dla sprawy. Nie ma więc podejrzenia o podstęp $z$ jej strony. Nie ukrywa ona przecież ciemnych stron swego życia. Jest osobą prawdomówna, co potwierdzają: pozwany, świadkowie i duszpasterz. Trzeba też wziąc uwagę, że zeznania procesowe miały miejsce ok. $2000 \mathrm{~km}$ od siedziby Sądu przy pomocy sędziego delegowanego, który, jakkolwiek dokonał przesłuchania bardzo dobrze, to jednak nie jest on kanonistą i w trudnych przypadkach nie zastapi wykwalifikowanego sędziego, zadającego z urzędu dodatkowe pytania.

Kanon 1679 w powiązaniu z kanonem 1536 § 2 KPK z 1983 roku dopuszcza możliwość przyznania mocy pełnego dowodu nawet w sprawach dotyczących dobra publicznego (a do takich należą sprawy małżeńskie) zgodnym zeznaniom stron procesowych tylko wtedy, gdy ,dochodzą inne elementy, które je ostatecznie wzmacniają". Nie ma wątpliwości, że w sprawie W. - Ł. takie elementy mają miejsce. Są nimi: niepodejrzaność stron, zwłaszcza powódki, potwierdzona opinią świadków i duszpasterza i przede wszystkim zeznanie niepodejrzanego świadka (F. H.). Rota Rzymska w swoich orzeczeniach niejednokrotnie opiera się na nie budzących podejrzeń zeznaniach jednego tylko świadka (Zob. J. Grzywacz, Moc dowodowa zeznań świadków według nowego Kodeksu Prawa Kanonicznego, RTK 32, z. 5, s. 31-50).

Wymienione wyżej argumenty dają moralną pewność, że przy zawieraniu tego małżeństwa nie miała miejsca prawidłowo zastosowana nadzwyczajna forma kanoniczna.

Strony zgodnie zeznały, że małżenstwo ich nie zostało nigdy. konwalidowane. Również świadkowie nie słyszeli, aby strony kiedykolwiek ponawiały zgodę małżeńską, czy w inny sposób starały się o uważnienie nieważnego małżeństwa wobec Kościoła katolickiego. Sama historia życia stron procesowych wyklucza taką możliwość. Strony zawierając małżeństwo w 1961 roku były dalekie od jakiejkolwiek religii. Przez cały czas trwania wspólnoty małżeńskiej do 1965 roku nie odczuwały 
potrzeb religijnych, w tym również ewentualnego konwalidowania nieważnego małżeństwa. Powódka nawrócenie religijne przeżyła dopiero w 1982 roku, po siedmiu latach trwania $w$ cywilnym małzeństwie $z$ innym mężczyzną. Pozwany do dziś ma luźny związek ze swoją religia prawosławna.

Zgromadzony materiał dowodowy daje moralną pewność, że powódka byla prawnie zobowiązana do katolickiej formy zawarcia małżeństwa, zastosowania zwyczajnej formy kanonicznej nie byto możliwe, forma nadzwyczajna została zastosowana wadliwie, a tak zawarte małżeństwo nie było nigdy konwalidowane.

\section{Orzeczenie}

Po rozważeniu przytoczonych wyżej zasad prawa kanonicznego i danych faktycznych ustalonych podczas procesu, Międzydiecezjalny Sąd I Instancji w Grodnie, mając tylko Boga przed oczyma, na postawiona wyżej wątpliwość: Czy udowodniono nieważność małżeństwa W. $-\succeq$. $\mathrm{z}$ tytulu braku nadzwyczajnej formy kanonicznej, odpowiada t w i e r d z ą c o, czyli orzeka, że małżeństwo Aleksandra Iwanowicza Ł. $_{\text {. }}$ i Emmy Johannesowny W. zostało zawarte $n$ i e wa ż n i e.

Wyrok nie jest prawomocny. Wymaga przejrzenia i zatwierdzenia przez Sąd II Instancji. Grodno, dnia 30 maja 1995 roku. 